Stefka G. Eriksen, Karen Langsholt Holmqvist, and Bjørn Bandlien

\title{
Approaches to the Self - From Modernity Back to Viking and Medieval Scandinavia
}

\begin{abstract}
In this article the editors of the book account for the book's main aims, namely to discuss various modes of studying and defining the self and to investigate the various processes and practices that selves in Viking and medieval Scandinavia engaged with. In the book, these two research questions are discussed based on various representations and conceptualizations of the self in textual, historical, art-historical, and archaeological sources from western Scandinavia. Thus, the book aims to contribute to (1) studies of the self in Viking and medieval Scandinavia; (2) studies of the medieval self in general; and (3) theoretical discussions on the interconnections between cognition, materiality of cultural expressions, discourses and practices. This introductory article accounts for the historiographies of these fields and the structure of the book.
\end{abstract}

Keywords: agency, blending theory, choosing / choice-making, cognitive theory, cultural theory, homo economicus, homo sociologicus, practice theory, rational choice theory, social theory, wayfinding

This book has two main aims. First, the book will discuss various modes of studying and defining the medieval self. This will encompass a wide range of source material from Scandinavia, c. 800-1500, such as archaeological, architectural and artistic, documentary and literary sources, and runic inscriptions. The second main aim of the book will be to discuss what processes and practices the self engaged with in this cultural context, by studying various textual and material representations and conceptualizations of the self.

The first question that probably occurs to most readers of this book is: What is the self? The book as a whole will not seek to give a unified answer to this question as it will not deploy a single theoretical and methodological approach. Rather, the individual articles will take on different approaches to the self, inspired by theories such as cultural theory, practice theory, or cognitive theory, or prioritizing close reading of the empirical material. The book does

Stefka G. Eriksen, Karen Langsholt Holmqvist, Norwegian Institute for Cultural Heritage Research

Bjørn Bandlien, University of South-Eastern Norway

Ә Open Access. (C) 2020 Stefka G. Eriksen et al., published by De Gruyter. (cc) BY-NC-ND This work is licensed under a Creative Commons Attribution-NonCommercial-NoDerivatives 4.0 International License. https://doi.org/10.1515/9783110655582-001 
not seek to give a new definition of the self, but rather it aims to engage with the current discussions and investigate how the various definitions of and approaches to the self may complement each other. Based on interdisciplinary investigations and with such a theoretically varied starting point, our aim is to learn more about how our own scholarly mindsets and horizons condition what aspects of the medieval self are "visible" and "investigable" for us. Utilizing this insight, we aim to propose a more syncretic approach towards the medieval self, not in order to substitute excellent models already in existence, but to foreground the flexibility and the variance of the current theories, when these are seen in relationship to each other. The self and how it relates to its surrounding world and history has always been and will continue to be a main concern of humanities and social sciences. Focusing on the theoretical and methodological flexibility when approaching the medieval self has the potential to raise awareness of our own position and agency in various social spaces today.

\section{The Modern Self}

The book contributes to and, therefore, needs to be positioned within three fields of studies. The most immediately relevant field is studies of the self in the Viking and medieval periods in Scandinavia ${ }^{1}$; the second is studies of the medieval self in general; the last is theories of the self within the humanities and social sciences in general. This introduction will present the main trends in these fields, in order to anchor our own investigations, starting with the broadest contextualization for the project.

The definition of the self has been a major topic of discussion in many fields and is grounded in the main paradigm shifts in social and cultural theory. The historiography of these major paradigms has recently been reviewed elegantly by Andreas Reckwitz (2002a). The individual, or the self, plays a major (if not a main) role in all type of social theories. Social theory explains human action either as motivated by purpose, intention, and interest (for example, Rational Choice Theory, where the individual is seen as "homo economicus") ${ }^{2}$

1 While the medieval period in Europe is traditionally dated to c. 500-1500, in Scandinavia this period is divided into the Viking Age, c. 800-1000, and the Middle Ages, c. 1000-1500.

2 This is reflected in Scottish moral philosophy, since its emergence at the end of the eighteenth century (Reckwitz 2002a, 245). 
or as motivated by collective norms and values (Norm-Oriented Theory, where the individual is seen as "homo sociologicus"). ${ }^{3}$

These two models of explaining the world have been challenged by the interpretative or cultural turn of social theory, also referred to as cultural theory, which emphasizes the symbolic structure of knowledge. Action is, according to this theory, motivated by collective cognitive and symbolic structures where "shared knowledge" ascribes meaning to the world. Cultural theory is based on and includes structuralism and semiotics, phenomenology and hermeneutics. It may be divided into cultural mentalism, cultural textualism, and cultural intersubjectivism. These sub-theories explain the social and the shared, and the locus for the social, differently. Culturalist mentalism places the social in the mind, as the mind is the place for knowledge structures. ${ }^{4}$ The social and the cognitive overlap in the mind, as they are pursued in the same place. Culturalist textualism locates the social outside the mind, i.e., in signs and symbols, in discourses and "texts." Culturalist intersubjectivism locates the social in the interaction, in the language, in the speech act. The social happens when the minds interact with each other linguistically. ${ }^{6}$

Practice theory, or theory of social practices, is also a part of cultural theory, but it forms a conceptual alternative to the previous three (Schatzki 2001a). It does not place the social in the mind, nor in the "text," nor in the interaction, but in the practice. ${ }^{7}$ Practice is defined as the whole of human action, the pattern that may be filled out by various individual acts. Practices are thus social, but they are carried out by individual bodies and minds. Even though it is deeply rooted in the work of Wittgenstein and Heidegger, practice theory presents a considerable shift in the perspectives on body, mind, things, knowledge, and discourse. Practices are seen as learned and routinized bodily performances which include both technical (any handicraft) and intellectual skills (talking, reading, writing) (Reckwitz 2002a, 251). Practices are also sets of mental activities - routinized ways of understanding the world, of knowing how to do something, of desiring something. The mental patterns are not part of the individual's interior

3 Reflected in the work of Durkheim and Parsons (Reckwitz 2002a, 245).

4 Reflected in the work of classical structuralists as Ferdinand de Saussure and Claude LéviStrauss, among others (see Reckwitz 2002a, 247).

5 Reflected in the work of Clifford Geertz, Michele Foucault, Niklas Luhmann (see Reckwitz 2002a, 248-249).

6 See, for example, the work of Karl Popper and Jürgen Habermas (see Reckwitz 2002a, 249).

7 Practice theory is exemplified by the work of authors such as Pierre Bourdieu, Anthony Giddens, the late Michel Foucault, Bruno Latour, Charles Taylor, and Theodore R. Schatzki (see Reckwitz 2002a). 
subjectivity, but of the practice. A practice thus deletes the distinction between outside and inside, between body and mind (Reckwitz 2002a, 252). Carrying out a practice means also the utilization of certain things - things can enable or limit certain bodily and mental activities (Reckwitz 2002b). In practice theory, discourse and language do not have the same central position as in other cultural theories. A discourse is just one type of practice and language exists in its routinized use. Social practices are routines of knowing, doing, using things, of understanding, or interconnecting and these routines create social structure.

Most significant for us here is that according to practice theory, the various routines and practices are carried out by individuals, but the individual consists of numerous "agents" who carry out the individual practices (Reckwitz 2002a, 256). The individual then becomes the unique crossing point of different mental and bodily routines and practices. ${ }^{8}$ This is radically different from how the individual, or the self, is seen by the other theoretical paradigms. In Marxist theory, for example, the individual is a product of the dynamics and conditioning factors of social class, social relations, or power (see, e.g., Taylor 1989). In their quest to balance structure and agency, many post-modernists prioritize the mess and tangle between agency and structure - the discourse itself - over individual agency. Discourse and language have also been prioritized over agency, with agency seen as a product of discourse. Some scholars have, however, argued for the compatibility and duality of the relationship between self and social structures, viewing the individual as a constant function of social life, not a remainder of it (see, e.g., Giddens 1984). Scholars have also discussed the availability of multiple selves, or roles, within one and the same individual, and the inner and social conflicts that may arise because of the availability of such multiple, and often conflicting, selves. Such observations have led to debates of the corelessness of the self, i.e., that the self is undefinable on its own, but is either imposed on us, or is borrowed, mirrored, or reflected. Practice theory promotes the core of the individual, even though, or maybe precisely because, it is the crossing point of many "agents" that carry out individual practices, which are representatives of learned and routinized, bodily and mental performances.

Practice theory is often vague, however, on the motivational premises for why the individual engages in the various practices, and not least for how the individual chooses between a variety of possible practices, especially if they are conflicting. In other words, how does an individual make choices? How may an individual's choice, and thereof, continuity or change in practice, be explained?

8 For a further discussion on the link between emotions and affects (the human mind), artifacts, and spaces, as primary characteristics of the social, see Reckwitz (2012). 
According to social and cultural theory, the choices may be based on inner intentions, collective norms, a sense of stability and predictability, discourse, language, learned routines and practices. These are all highly relevant motivations, but they do not account for scenarios where the motivations are conflicting. A few attempts at explaining choices and change within practice theory are made in recent works, where scholars suggest various factors which may lead to change. Schatzki (2001b) points to what he terms teleoaffective structures, combining the agent's intentions and affects, as a factor in practices. ${ }^{9}$ Reckwitz (2012, 255) discusses affects in combination with spaces in a recent article, and stresses the "destabilising and inventive potentials of affects and spaces".

The dynamics of an individual's choice, and thus continuity and change in a practice, is explained differently by cognitive theory. According to cognitive theory, the self is genuinely unstable and immensely flexible: because of our immense cognitive abilities, we humans have an endless array of possibilities of actions and choices every single time we need to choose to do something. The endlessness of our cognitive possibilities threatens our social existence, as a certain level of predictability is necessary in order to engage in a successful social interaction. From an evolutionary perspective, humans have solved this dilemma by creating social norms, unified by common originand identity-narratives, often expressed symbolically by visual and complex metaphorical expressions (Engel 2005). On a minor scale, every single choice an individual makes is, according to cognitive theory, an endlessly flexible process (Engel 2005). Choices are thus made not based on stable parameters but on conceptual blends, when the projections to the blend are highly selective and may include memories of previous selves, ideas of others, known narratives, and imaginations (Turner 2014, chapter 4, 65-106). Blending may include analogies, signifying continuity of the self, and disanalogies, signifying a change in the self. Blending, that is choosing, selves may thus be seen as wayfinders. In order for them to be successful in their social interactions, the wayfinding does not need to be entirely stable (as proposed by economic/ social theory), but sufficiently predictable, which is a much more obtainable goal. This is precisely one of the main insights one may gain from the humanities: world literatures, art, religions, and philosophies, including medieval cultural expressions, may reveal the limitlessness of human flexibility and the huge potential for cultural variance. ${ }^{10}$

9 See also Caldwell (2012), who discusses the concepts agency and change, as defined by Schatzki (2001a).

10 This line of thought is further expanded and discussed by Eriksen and Turner in this volume. 
As much as cognitive theory promotes cognitive flexibility, it does not neglect the fact that cognition is always social, it happens in a given environment, within a given body, with the help or obstructions of certain things. The way we think and the way we are happens in relation to other people, in social contexts and relationships. ${ }^{11}$ The way we think is also conditioned by our gender, bodies, abilities, and disabilities. The places and environments we inhabit function as context for our cognitive processes and we use things and objects in order to materialize, manifest, and realize our thoughts in a physical, perceivable world. Cognition is thus not only always social, but it is situated, embodied, embedded, extended, and distributed (Giere and Moffatt 2003; Clark 2012; Clark and Chalmers 2010). It is easy to see that many of the parameters that cognitive theory emphasizes are also essential for practice theory, as well as for other social and culture theories, albeit in different ways. The parameters and variables for discussing the self emerge thus as the common denominators of the theories, while the causal relationship between them varies.

\section{The Medieval Self}

According to this brief state-of-the-art of studies of the self, the self hovers between practices, routines, and cultures, and its own flexible nature and limitless cognitive potential. These theoretical discussions have certainly influenced the study of the medieval self as well. According to one of the forefathers of the debate, Colin Morris (1972), the individual emerged first in the twelfth-century and the manifestations of this emergence are, among others, the opening up of new professional opportunities, the possibility of personal choice of pursuing those professions, expansion of education, rediscovery of the classical past through textual adaptation and translation, personal piety and private confession, introduction of the idea of self-examination throughout society, the appearance of new genres such as autobiography. Caroline Bynum (1984) proposes one main corrective to this hypothesis, which concerns the importance of the social space for the emergence of the individual. She shows how the Church and the Gregorian Reform was the main context for the individual's, or the self's (as she calls it), desire, choice, and agency to imitate, to conform, to belong. It was the Church which formalized in 1215 that each layperson had to confess to his and her parish priest at least once a year. By doing this the Church succeeded in producing individuals,

11 On the interface between concepts like "situated cognition" and social psychology, see Smith and Conrey (2012). 
but mostly because that was in the institution's own interest when claiming its own power in a contest with the royal powers. ${ }^{12}$

In this discussion, we obtain a glimpse of the "homo economicus" motivated by his own purpose, the significance of the social context, the discourse, the norm, as well as the individual engaging in practices. Many other aspects of the self have been promoted as primary and defining in the debate as a whole. Sometimes scholars have foregrounded the inner self, exploring traces of inward reflection and spiritual exploration (Jaeger 1987; Stock 1995, 2017; Kramer 2015), the cognitive or intellectual self (de Libera 1991; Carruthers 1998; Jaeger 1987, 2002; Wei 2012, 8-47; Copeland 2001; Le Goff 1993), the creative self (Morris 1972; Minnis 1984; Copeland 1991; Dagenais 1994; Binski 2010; Sandler 2010), or the emotional self (Hanning 1977; Rosenwein 1998, 2006). Some scholars have placed primary emphasis on the social self, i.e., the self's participation in social communities (Perkinson 2009; Shaw 2005; Bynum 1984), while others have emphasized the specific role an individual could have in a community, i.e., a knight, an intellectual, a priest, a tradesman, etc. (Le Goff 1990, 1993; Gurevich 1995; Wei 2012; Jaeger 2002). Yet others have investigated medieval sources for what they tell us about the roles the self sought or had to perform in various contexts (Crane 2002; Belting 2011, 62-63). A main contention within medieval studies is thus that the complexity - not the reconciliation but the combination of paradoxes (for example, inner and social, religious and intellectual, rational and emotional) - is a prime feature of the medieval self, which needs to be studied within a specific temporal and socio-cultural context (Bynum 2011).

The material turn in many disciplines has also emphasized that medieval artifacts are cultural expressions, with the primary characteristic that they are artifacts made by and for people. This has made the link between medieval selves (who are forever gone) and the material culture (which is the only remnant left) much more explicit. ${ }^{13}$ The material turn in the humanities also allows for new interdisciplinary and parallel approaches to studying the medieval self, based on manuscripts, art, architecture, with the aim of investigating the variety in the dynamics between the self and the materiality of cultural expressions.

Recently various scholars have added new, previously unconsidered factors to the discussion. David Gary Shaw (2013), for example, argues that the nature of the self's agency has not been taken in consideration enough. According to

12 A similar argument was also proposed more recently by Verderber (2013), see below.

13 On material philology, see Nichols 1990; on illuminated manuscripts and art, see Ladner 1965; Belting 2011; Smith 2012; Bynum 2011; on materiality in archaeology, see Olsen 1997, 2010, 2012. 
him, the self's agency comes prior to expression, and therefore the self is accessible independent of texts, discourses, languages, and social structures. Shaw argues that the self is always social, but nevertheless has agency, which is primarily a cognitive change that depends on mental and bodily experience. Agency thus constitutes a narrative. Indeed, even if the self represents a type, if the self conforms, or is narrated as passive, the agency of the self remains primary. Shaw's ideas invite the recovery of the self, which is sorely needed after its deconstruction, and the present anthology responds to this challenge: the self is here given center-stage and is seen with all its complexities and in relation to multiple cognitive processes, social interactions, and discourses.

Suzanne Verderber (2013, 4-5) also foregrounds the self's agency, cognition, and self-reflection, even though her argument follows a different line of thought. She criticizes the presupposition that individualism is "the natural, universal, predetermined, and desirable model of subjectivity," the so-called "sleeping beauty effect." ${ }^{14}$ Verderber points out the difficulties related to giving a concise and stable definition of the term "self" and "individual" in many scholars' work and wonders how, in so many studies, the individual ends up being seen in opposition to social forces (Verderber 2013, 6-8). ${ }^{15}$ Her main argument is that the medieval self does not emerge necessarily as a consequence of the Gregorian Reform. What she calls subjective interiority rather enables the space to appear, as a result of the clash between secular and priestly power (Verderber 2013, 13). In such a situation of a conflict between various social spaces, an individual is bound to turn inwards and reflect upon the set of ideals promoted by the two "powers." In a space where the individual is made to choose, the need to choose demands of the self that it exist between the inside and several outsides. The main tool to navigate between these spheres is reflexivity and self-examination.

One aspect that is common for Shaw and Verderber is that, without explicit references to cognitive sciences, the self's agency, self-reflection, and cognition are emphasized, without neglecting the significance of the cultural and social context.

14 Her argument is inspired by the philosophy of Friedrich Nietzsche, Michel Foucault, Gilles Deleuze, and Jacques Lacan.

15 For a discussion on terms such as subject, individual, agent, actor, and with the greatest focus on subject and subjectivity, see Rebughini 2014. 


\section{Medieval Scandinavian Selves}

The context that this anthology engages with most immediately is medieval Scandinavia. This is a vast and complex "context” or "entity" to work with, as during various historical periods it has included Denmark and Sweden, Norway and Iceland, parts of modern Scotland and the islands in the North Sea. In scholarship, focus often falls on parts of medieval Scandinavia. In philology and literary scholarship, there is often a schism between East Norse (Swedish) and West Norse philologies and literatures. Archaeologists often focus on peculiarities of specific sites and urban settlements. Art historians, similarly, give priority to the specific details of the architectural and visual heritage in specific areas. The main reason for this is, obviously, the vastness of an endeavor to cover a certain topic in the whole area. In this book, the main focus will fall on medieval western Scandinavia, namely Norway and Iceland, but a few of the articles investigate the self in medieval Sweden and Denmark, based on textual, archaeological, and art-historical material.

A historical fact which makes the study of the self in medieval Scandinavia especially interesting is that the area became Christian much later than most parts of Europe. Denmark was Christianized by Haraldr blátonn in 975, as mentioned on the Jelling Stone. Norway and Iceland became Christian around the year 1000, albeit under different circumstances. The realms of Denmark, Norway, and Sweden established their own bishoprics in 1104, 1152-53, and 1164, respectively. So, while the individual and the self were perhaps emerging in continental Europe during the twelfth century under the influence of the Gregorian Reform or on account of the clash of secular and priestly powers, the Scandinavian context offers a different political, social, and religious space. The main raison d'être of the book is to discuss what processes and practices the self engaged in in this context.

Because of the book's focus, a short review of current studies of the self in medieval Norway and Iceland is most relevant. Unsurprisingly, the main scholarly paradigms, as described above, are traceable in this field as well, even though maybe not all aspects of the theories are adequately discussed. Historians have addressed such topics as general notions of the individual, individuality, and kingship (Bagge 1998a; Bagge 1998b); the notion of "Norwegian" or "Icelandic" national identity (Lunden 1995); the construction of social identity of specific historians, writers, and poets, such as the mythographer and politician Snorri Sturluson (d. 1241) (Wanner 2008; Torfi H. Tulinius 2004) or that of the knight and lawspeaker Haukr Erlendsson (d. 1334) (Sverrir Jakobsson 2007).

Philologists and literary scholars have been concerned with the creative selves, i.e., scribes, authors, translators, as well as the created selves of the 
literary characters within the texts. The field has gradually moved away from the stronghold of the "Icelandic school" of scholarship that dominated much of the twentieth century, and which promoted the originality of the Icelandic author, and downplayed the significance of religious texts, translations, or European influence. The latter has been afforded much greater consideration in recent years: Icelandic textual culture, with its uniqueness and peculiarities, is seen as inseparable from the rest of European literary heritage, religious and secular, in Latin and in the vernacular. In recent years, under the influence of material philology, studies of the creative self are more nuanced and take interest not only in notions of authorship, but also in the modes of other creative selves such as translators, scribes, rubricators, illuminators, etc. (Quinn and Lethbridge 2010; Ranković 2012; Eriksen 2014). The created self has also been studied, most often by focusing on the psychology and emotions of the characters in specific episodes or sagas (Miller 2014; Ármann Jakobsson 2008; Sif Ríkharðsdóttir 2017).

The self has been discussed from an art-historical perspective as well, as for example in studies of twelfth and thirteenth century sculpted heads in Scandinavian churches that have been interpreted as representations, or portraits, of specific rulers (Svanberg 1987). The individuality of architects, artists, and manuscript illuminators has also come to the fore recently, often contextualized within a discussion of how artistic schools and workshops conditioned an artist's room for creativity (Kausland 2016; Liepe 2009). Archaeologists have discussed concepts like identity, ethnicity, gender, and social class based on various groups of excavated materials (Olsen 1997, 2010), and recent scientific methods, such as isotop-analysis, allow for a much more direct study of the medieval individuals, how they lived, what they ate, where they came from, and how they died (Naumann, Price and Richards 2014).

\section{Aim of This Book}

Aiming to build upon and complement the current scholarly debates, this anthology has two main goals. First, we aspire to investigate the self not in a theoretically and methodologically uniform way, but in a theoretically and methodologically explicit way. The authors experiment with various approaches to the medieval self, and the book as a whole will reveal how the difference in our own standpoint as researchers conditions the way we perceive of the medieval self. This will be done based on various types of sources - texts of various genres and languages (Middle English, Old Norse, and Latin), runic inscriptions and Roman alphabetic manuscripts, manuscripts as cultural objects, art and architecture, and archaeological 
remains. Second, the book will discuss what processes and practices the self engaged with in the cultural context of Viking and medieval western Scandinavia. We will focus on what the self does within this culture and its numerous social spaces: are the self's choices and expressions conditioned by the social spaces, or vice versa? Further, we will discuss how the dynamics between the self and social spaces are conditioned by the materiality, genre, discourse, and language of the material studied. Is the self conditioned by external factors or does the self come prior to cultural expressions? The book does not aim for an exhaustive discussion of the self in Viking and medieval western Scandinavia, but it aims for breadth and variety with regard to theoretical starting points, approaches, and sources used. This has the potential to reveal overlap and compatibility between the various approaches, when seen in relationship to each other, and this may potentially contribute to the existent debates of medieval and modern selves.

\section{Structure of the Book}

The articles in this book adopt a variety of approaches to the medieval self, sometimes anchored in a specific theoretical starting point, other times experimenting with an eclectic combination of theories. The first introductory article of the book by DAVID GARY SHAW adopts exactly such an eclectic approach to the self, experimenting with an eclectic combination of theories. Shaw develops further some of the perspectives mentioned in this introduction, combines them with a series of others, and tests them out in a case study on traveling selves in fifteenth-century England. This article demonstrates how combining various theories may play out in the study of the medieval self, and it is therefore of central significance in the narrative of the book as a whole. Shaw's observations on theoretical eclecticism will be followed by various studies of the self, based on Scandinavian material, c. 800-1500, mostly from Norway and Iceland, but also from Denmark and Sweden.

The majority of the articles in the book discuss one type of cultural expression, i.e., a text, an object, a building, or an archaeological site. Therefore, the main organizational principle of the book will be based on the type of materiality of the cultural expression studied. This organizational principle is, however, not intended to create divisions between the different materialities, but rather to highlight the fluidity and overlaps between the discussions. A few of the authors discuss the representation of the self in different materialities, and in the book as a whole, we search to investigate how the representations of the self are conditioned by materiality. 
In the first part of the book, authors discuss selves based mostly on texts (Eriksen and Turner, Steen, Torfi H. Tulinius, Bandlien, Johansson, Eriksen, Diesen, Rønning Nordby). There are, however, several variables that show the complexities of studying the self, based on text. (1) Textual materiality: Texts are studied on various levels: as a text work (Eriksen and Turner, Steen, Torfi H. Tulinius, Diesen, Rønning Nordby), as an oral composition (Johansson), based on a given manuscripts (Johansson, Eriksen), or based on the comparison between a text work and seals (Bandlien). (2) Genre: Texts belong to various genres, including royal historiographies (Steen and Bandlien), Sagas of Icelanders (Johansson, Torfi H. Tulinius, Eriksen), contemporary sagas (Torfi H. Tulinius), skaldic poetry (Johansson), hagiography (Diesen), and law material (Rønning Nordby). (3) Language: Texts are written either in Latin (Diesen) or in the vernacular Norse (everyone else). (4) Theory: Last but not least, texts are studied either from a cultural perspective (esp. Torfi H. Tulinius, Bandlien), cognitive perspective (esp. Eriksen and Turner, Steen, Eriksen), or from an empirical perspective (esp. Johansson, Rønning Nordby).

In the second part of the book, the self is studied based mostly on artifacts, buildings, or other types of material remnants (Naumann, Croix, Bauer, Bonde, Holmqvist). These studies also vary according to similar variables. (1) Materiality: The self is studied based on human remains / skeletons (Naumann), archeological artifacts and sites (Croix), urban buildings (Bauer), medieval churches (Bonde, Holmqvist), physical spaces with runic inscriptions (Holmqvist), or comparison between material artifacts and textual and linguistic expressions (Bauer, Holmqvist). (2) and (3) Genre and language are not equally easy to discuss based on material artifacts, but the discourses taking place may be classified depending on the degree of formality of the context where the artifacts are used or produced, i.e., formal / political / religious contexts (Bauer, Bonde, Holmqvist) or domestic / informal contexts (Croix, Holmqvist, Naumann). (4) The authors use various theoretical starting points here, too, including cultural and practice theory (Naumann, Croix, Bonde, Holmqvist), cognitive theory (Holmqvist), or with focus on the empirical material (Bauer) [see table below].

After Shaw's introductory essay, STEFKA G. ERIKSEN and MARK TURNER debate how cognitive theory may contribute to perceiving the selves responsible for and represented in the Old Norse literary corpus, by focusing on four main topics: the cognitive premises for cultural variation; blending and creation of stories; the conception of a stable self; making choices. These discussions are illustrated with examples from a wide range of Old Norse poetry and prose and conclude with a reflection on the complementarity of traditional philological / literary and cognitive interpretations. FRANCIS STEEN elaborates further on the usefulness of cognitive theory when reading Old Norse royal historiography, by 
taking a closer look at Sverris saga and reading it as a representation of human cognition. Steen recounts the self's amazing ability to perceive promising possibilities and available affordances and demonstrates how King Sverrir has an unusual capacity for perceiving possibilities, how he successfully exploits and navigates all the options available to him, no matter how remote his chances are, but how, at the end of his reign, he is unable to escape the downside consequences of the precarious self. BJøRN BANDLIEN continues the discussion of Sverris saga, and as a juxtaposition to Steen's cognitive analysis, he leans on cultural theoreticians such as Bourdieu, Lefebvre, and Bakhtin. He reads King Sverrir's upbringing and early education as a priest on the Faroe Islands, the development of his career, and his later kingship as a testimony to a dialogic self - the king is both a lion and a lamb. Bandlien discusses whether the same doubleness is represented in the visual images on King Sverrir's seal. Bandlien reads Sverris saga as a twelfth-century text work, contextualized in the time it was supposedly written. A similar approach is adopted by TORFI H. Tulinius, who addresses the topics of inner subjectivity, individuality, and sense of otherness in Sturlunga saga and some of the Sagas of Icelanders, written during the twelfth and thirteenth century. He shows how the demands on the individual, juxtaposed with the rise of pastoral power, were often at odds with social customs, even two to three hundred years after the conversion. In the next article, KARL G. JOHANSSON problematizes the method used so far and shows that the "self" in a medieval text may represent at least three different selves. Using the poem Sonatorrek as an example, Johansson argues that the self represented in it can be either the self of the tenth-century poet Egill Skallagrimsson; the self of the author or compiler of the thirteenth-century Egils saga, who chose to include just the first stanza of the poem; or the self of the compiler of the seventeenth century manuscript where the whole poem is preserved. STEFKA G. ERIKSEN pursues this latter perspective even further by focusing on the materiality of medieval manuscripts as a source for the scribe's and reader's selves. Studying two manuscripts of Njáls saga, Eriksen shows how the way the manuscripts were written and the way the texts were structured by initials may reflect the senders' intentions to infuse the text with a given meaning and to invite the readers to pursue their own meaning-making and interpretative process.

So far, all texts discussed have been narrative, including both historiographical genres and fiction. The next analysis of the medieval self in text, by OLEALBERT RøNNING NORDBY, focuses on the normative genre of legal texts from thirteenth-century Norway. Rønning Nordby studies the development of einseiðr, an oath type that allowed an individual to swear by himself without oath helpers, and thus examines how the use of the concept of individuality developed in medieval customary law, influenced by and in contact with systems of learned law. 
The last article in the text-focused section of the book changes to another variable of text, namely language. RAKEL IGLAND DIESEN turns to the agency of children as represented in Nordic hagiography from the Middle Ages, in both Latin and the vernacular (such as Icelandic bishops' sagas and miracles). Including children as a social group expands the history we can tell, including that about the medieval self. Many of the children in these sources are disabled or impaired and then miraculously cured. Diesen argues that the sources reflect both children's actions and voices, as well as the agency and lived experience of the children themselves. However, the sources are seen as a combination of the point of views of the miraculés, the community, the hagiographer. Through transmission, the sources may have become prescriptive about how to engage in devotion and pilgrimage and how to perceive of children as devotional agents.

In the second part of the book, the authors turn to representations of the self in material sources, other than manuscripts. ELISE NAUMANN discusses the individual through the concept of human biographies and based on archaeological human remains from the earliest phase of medieval Oslo. She argues that even then, $c$. 1000-1200, individuals had a sense of identity which could be pursued and developed through everyday habits, such as eating various types of foods. As today, the type of food people ate seems to have been closely related either to a self-chosen sense of self or socially defined identity. SARAH CROIX also discusses the process of self-identification, by focusing on the activity of weaving in various settlement sites. She argues that the experience of the gendered self is a correlate of the individual's social status, which defines specific boundaries within which their sense of agency may be facilitated or inhibited. This is done through the performance of the same activity taking different meanings depending on who, where, and for what purpose it was conducted. Other types of activities that seem to have been linked to a sense of self, selfassertion, or private ownership is discussed by EGIL L. BAUER. He juxtaposes the change in tenement structures in medieval Oslo, c. 1200-1500 as revealed by archaeological excavations, on the one hand, and the change in Oslo tenements named after individuals in the Norwegian diploma material, on the other. The study of changing patterns is focused around periods of known medieval fires and the Black Death. Based on the change-patterns in the two source groups, Bauer argues that the names of named tenements in medieval Oslo may have had different functions through time, spanning from marking private property, to simply designating a specific place without reflecting the identity of the owner. Studying the two source groups together reveals new insights about processes of claiming private property, signifying social status, and the development of the urban population in medieval Oslo. LINE M. BoNDE turns to a different type of buildings, namely Danish churches during the long twelfth century, and 
argues that one of their main and most repetitive decorative motifs - the arcademotif - may be understood as reflecting an intended social and ritual practice. Bonde argues that the arcade was intended to function as a framework during the ritual practice, which was to trigger the self's memory and cognitive process of identifying and relating personal, local, and universal history. In conclusion, KAREN LANGSHOLT HOLMQVIST studies the interaction between architectural structures and verbal expressions of self. She turns to another group of individual expressions, namely those of the Norse people who left runic inscriptions on the walls of the medieval Nidaros Cathedral in Trondheim and on the Neolithic chambered tomb of Maeshowe, Orkney. A medieval cathedral and a Neolithic tomb offer widely different contexts for a carver wanting to leave a runic inscription, and Holmqvist discusses how the physical and cultural context contributed to shaping the inscriptions. Moreover, she studies the selves represented in the inscriptions and discusses whether these may be seen as a social practice or remnants of individual cognitive processes, or both.

Holmqvist's eclectic approach with regard to both the theoretical starting point and material studied takes us back to the main aims of this book, which will be emphasized in the concluding article of the book. Here the editors will collect the threads from the individual articles and return to the main questions: (1) How does a specific theoretical and methodological starting point condition the way we discuss the self, and what are the variables of the self that become visible depending on our chosen starting point? (2) How do the selves of Viking and medieval Scandinavia interact with the various social spaces of this cultural context, and how are these dynamics conditioned by the materiality, genre, language, and discourse of the material studied. Is the self conditioned by external factors, or does the self come prior to cultural expressions? Achieving these aims will provide relevant contribution to existent debates of medieval and modern selves. 


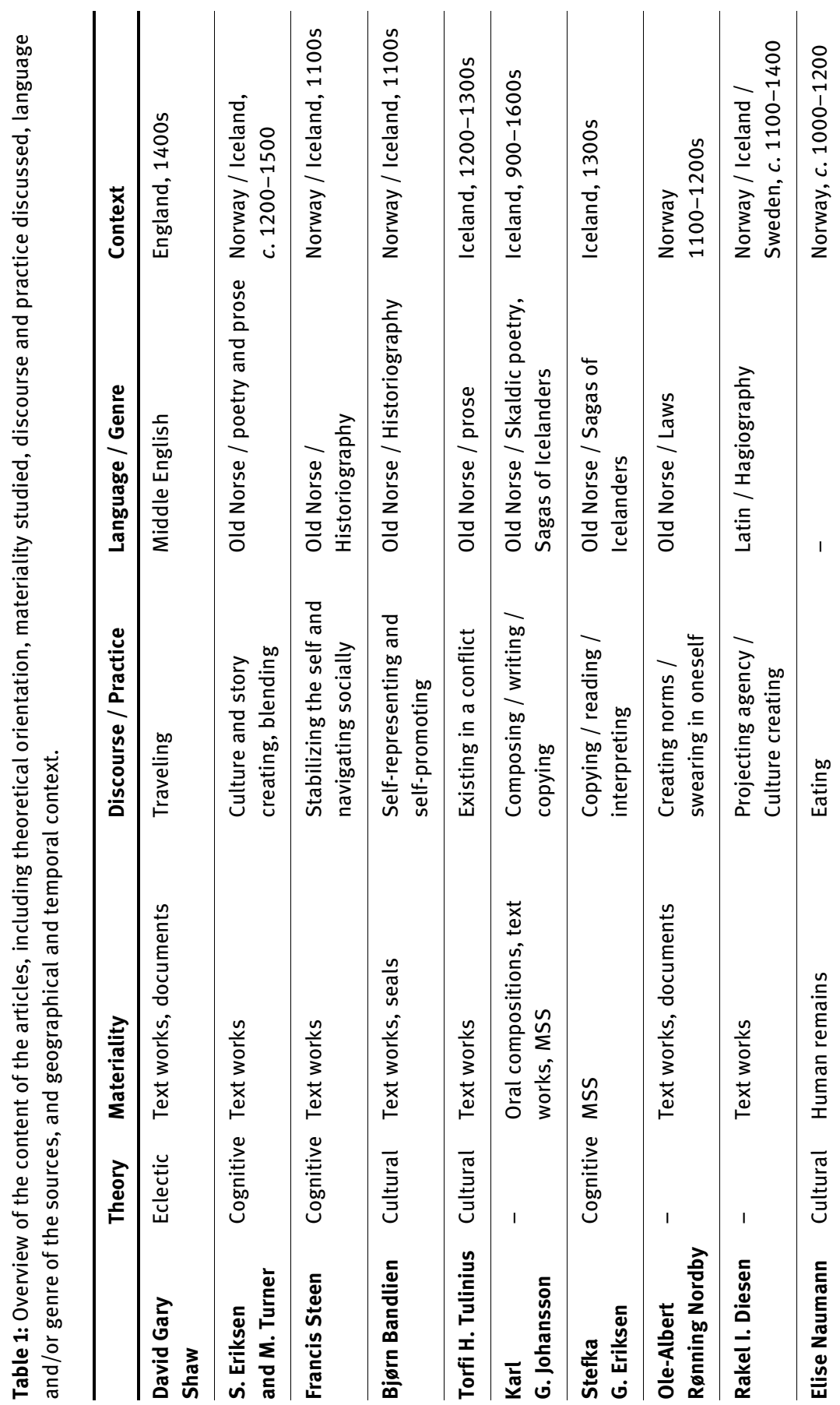




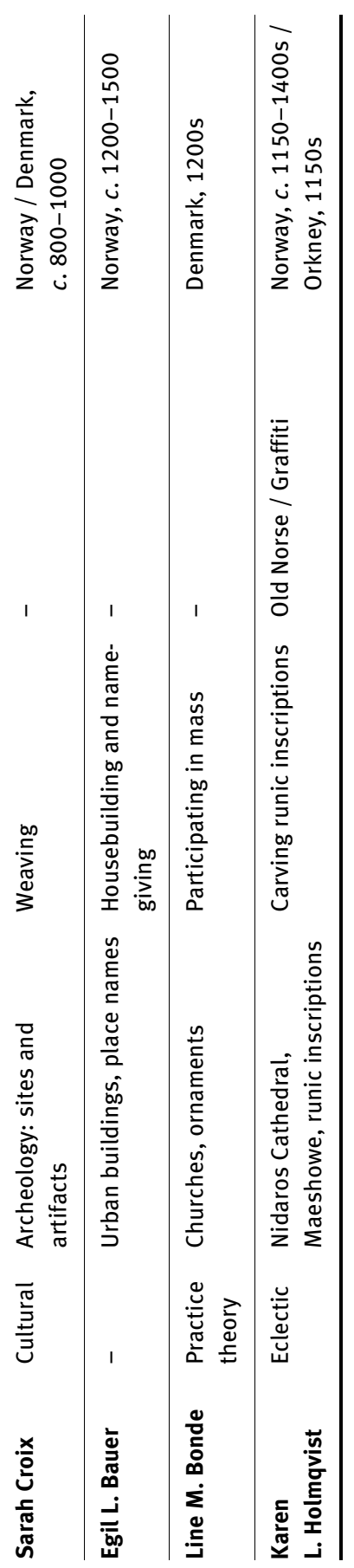




\section{References}

Ármann Jakobsson. 2008. "Egils saga and Empathy: Emotions and Moral Issues in a Dysfunctional Saga Family.” Scandinavian Studies 80: 1-18.

Bagge, Sverre. 1998a. Det Europeiske Menneske: Individoppfatninger fra middelalderen til $i$ dag. Oslo.

Bagge, Sverre. 1998b. "Kingship and Individuality in Medieval Historiography." In The Individual in European Culture. Ed. Sverre Bagge. European Legacy, 2, no. 8. 0slo. 25-41.

Belting, Hans. 2011. An Anthropology of Images: Picture, Medium, Body. Trans. Thomas Dunlap. Princeton.

Binski, Paul. 2010. “'Working by Words Alone': The Architect, Scholasticism and Rhetoric in Thirteenth-century France." In Rhetoric Beyond Words: Delight and Persuasion in the Arts of the Middle Ages. Ed. Mary Carruthers. Cambridge Studies in Medieval Literature, 78. Cambridge. 14-51.

Bynum, Caroline. 1984. "Did the Twelfth Century Discover the Individual?" In Jesus as Mother: Studies in the Spirituality of the High Middle Ages. Publications of the Center for Medieval and Renaissance Studies, UCLA, 16. Berkeley. 82-108.

Bynum, Caroline. 2011. Christian Materiality. An Essay on Religion in Late Medieval Europe. New York.

Caldwell, Raymond. 2012. "Reclaiming Agency, Recovering Change? An Exploration of the Practice Theory of Theodore Schatzki." Journal for the Theory of Social Behaviour 42.3: 283-303.

Carruthers, Mary. 1998. The Craft of Thought. Meditation, Rhetoric, and the Making of Images, 400-1200. Cambridge Studies in Medieval Literature, 34. Cambridge.

Clark, Andy. 2012. "Embodied, Embedded, and Extended Cognition." In The Cambridge Handbook of Cognitive Science. Ed. Keith Frankish and William M. Ramsey. Cambridge. 275-91.

Clark, Andy and David Chalmers. 2010. “The Extended Mind." In The Extended Mind. Ed. Richard Menary. Cambridge, Mass. 27-42.

Copeland, Rita. 1991. Rhetoric, Hermeneutics and Translation in the Middle Ages. Cambridge Studies in Medieval Literature, 11. Cambridge.

Copeland, Rita. 2001. Pedagogy, Intellectuals, and Dissent in the Later Middle Ages: Lollardy and Ideas of Learning. Cambridge Studies in Medieval Literature, 44. Cambridge.

Crane, Susan. 2002. The Performance of Self: Ritual, Clothing and Identity during the Hundred Years War. Philadelphia.

Dagenais, John. 1994. The Ethics of Reading in Manuscript Culture: Glossing the Libro de buen amor. Princeton.

Engel, Christoph. 2005. Generating Predictability: Institutional Analysis and Institutional Design. Cambridge.

Eriksen, Stefka G. 2014. Writing and Reading in Medieval Manuscript Culture: The Translation and Transmission of the Story of Elye in Old French and Old Norse Literary Contexts. Medieval Texts and Cultures of Northern Europe, 25. Turnhout.

Giddens, Anthony. 1984. The Constitution of Society: Outline of the Theory of Structuration. Cambridge.

Giere, Ronald N. and Barton Moffatt. 2003. "Distributed Cognition: Where the Cognitive and the Social Merge." Social Studies of Science, 33.2: 301-10. 
Le Goff, Jacques. 1990. The Medieval World. London.

Le Goff, Jacques. 1993. Intellectuals in the Middle Ages. Cambridge, MA.

Gurevich, Aaron. 1995. The Origin of European Individualism. Trans. Katharine Judelson. Oxford.

Hanning, Robert. 1977. The Individual in Twelfth Century Romance. New Haven.

Jaeger, C. Stephen. 1987. "Cathedral Schools and Humanist Learning, 950-1150." Deutsche Vierteljahsschrift 61: 569-616.

Jaeger, C. Stephen. 2002. Scholars and Courtiers: Intellectuals and Society in the Medieval West. Collected Studies Series, 753. Aldershot.

Kausland, Kristin. 2016. "Late Medieval Paintings in Norway - Materials, Techniques, Origins." Zeitschrift für Kunsttechnologie und Konservierung 30.1: 47-66.

Kramer, Susan. 2015. Sin, Interiority, and Selfhood in the Twelfth-Century West. Studies and Texts, 200. Toronto.

Ladner, Gerhart. 1965. Ad Imaginem Dei: The Image of Man in Medieval Art. Wimmer Lecture, 16. Latrobe, PA.

de Libera, Alain. 1991. Penser au moyen âge. Points, 329. Paris.

Liepe, Lena. 2009. Studies in Icelandic Fourteenth Century Book Painting. Rit, Snorrastofa, 6. Reykholt.

Lunden, Kåre. 1995. "Was There a Norwegian Identity in the Middle Ages?” Scandinavian Journal of History 20: 19-33.

Miller, William Ian. 2014. “Why Is Your Axe Bloody?” A Reading of Njáls saga. Oxford.

Minnis, Alastair J. 1984. Medieval Theory of Authorship: Scholastic Literary Attitudes in the Later Middle Ages. Worcester.

Morris, Colin. 1972. The Discovery of the Individual: 1050-1200. New York.

Naumann, Elise, T., Douglas Price, and Michael P. Richards. 2014. "Changes in Dietary Practices and Social Organization During the Pivotal Late Iron Age Period in Norway (AD 550-1030): Isotope Analyses of Merovingian and Viking Age Human Remains." American Journal of Physical Anthropology 155: 322-31.

Nichols, Stephen. 1990. "Introduction: Philology in a Manuscript Culture.” Speculum 65.1: 1-10.

Olsen, Bjørnar. 1997. Fra ting til tekst: teoretiske perspektiv i arkeologisk forskning. Oslo.

Olsen, Bjørnar. 2010. In Defence of Things: Archaeology and the Ontology of Objects. Lanham.

Olsen, Bjørnar. 2012. Archaeology: The Discipline of Things. Berkeley.

Perkinson, Stephen. 2009. The Likeness of the King: A Prehistory of Portraiture in Late Medieval France. Chicago.

Quinn, Judy and Emily Lethbridge, eds. 2010. Creating the Medieval Saga: Versions, Variability and Editorial Interpretations of Old Norse Saga Literature. Viking Collection, 18. Odense.

Ranković, Slavica et al., eds. 2012. Modes of Authorship in the Middle Ages. Papers in Mediaeval Studies, 22. Toronto.

Rebughini, Paola. 2014. "Subject, Subjectivity, Subjectivation.” Sociopedia.isa (2015): 1-11. Retrieved from http://www.sagepub.net/isa/admin/viewPDF.aspx?\&art=2nd\%20Coll\% 20Subject,subjectivity.pdf (accessed April 14, 2020).

Reckwitz, Andreas. 2002a. "Towards a Theory of Social Practices: A Development in Culturalist Theorizing." European Journal of Social Theory 5.2: 243-63.

Reckwitz, Andreas. 2002b. "The Status of the 'Material' in Theories of Culture: From 'Social Structure' to 'Artefacts'." Journal of Theory of Social Behaviour 32.2: 195-217. 
Reckwitz, Andreas. 2012. “Affective Spaces: A Praxeological Outlook.” Rethinking History 16.2: 241-58.

Rosenwein, Barbara H., ed. 1998. Anger's Past: The Social Use of an Emotion in the Middle Ages. Ithaca, NY.

Rosenwein, Barbara H. 2006. Emotional Communities in the Early Middle Ages. Ithaca, NY.

Sandler, Lucy Freeman. 2010. "Rhetorical Strategies in the Pictorial Imagery of Fourteenthcentury Manuscripts: The Case of the Bohun Psalter." In Rhetoric Beyond Words. Ed. Mary Carruthers. Cambridge Studies in Medieval Literature, 78. Cambridge. 96-123.

Schatzki, Theodore R. 2001a. "Introduction: Practice Theory." In The Practice Turn in Contemporary Theory. Ed. Theodore R. Schatzki, Karin Knorr Cetina and Eike von Savigny. London \& New York. 1-14.

Schatzki, Theodore R. 2001b. "3. Practice Mind-ed Orders." In The Practice Turn in Contemporary Theory. Ed. Theodore R. Schatzki, Karin Knorr Cetina and Eike von Savigny. London \& New York. 42-55.

Shaw, David Gary. 2005. Necessary Conjunctions: The Social Self in Medieval England. Palgrave-MacMillan.

Shaw, David Gary. 2013. "Recovering the Self: Agency after Deconstruction." In Sage Handbook of Historical Theory. Ed. Sarah Foot and Nancy Partner. Los Angeles. 474-95.

Sif Ríkharðsdóttir. 2017. Emotions in Old Norse Literature: Translations, Voices, Contexts. Studies in Old Norse Literature. Cambridge.

Smith, Eliot R. and Frederica R. Conrey. 2012. "The Social Context of Cognition.” In The Cambridge Handbook for Situated Cognition. Ed. Philip Robbins and Murat Aydede. New York. 454-66.

Smith, Kathryn A. 2012. The Taymouth Hours: Stories and the Construction of the Self in Late Medieval England. Toronto.

Stock, Brian. 1995. "Reading, Writing and the Self: Petrarch and His Forerunners." New Literary History 26: 717-30.

Stock, Brian. 2017. The Integrated Self: Augustine, the Bible, and Ancient Thought. Philadelphia.

Svanberg, Jan. 1987. Furstebilder under folkungatid. Skaraborg.

Sverrir Jakobsson. 2007. "Hauksbók and the Construction of an Icelandic Worldview." Saga Book 31: 22-38.

Taylor, Charles. 1989. Sources of the Self: The Making of Modern Identity. Cambridge.

Torfi H. Tulinius. 2004. Skáldid i skriftinni: Snorri Sturluson og Egils saga. Reykjavík.

Turner, Mark. 2014. The Origin of Ideas: Blending, Creativity, and the Human Spark. New York.

Verderber, Suzanne. 2013. The Medieval Fold: Power, Representation and the Emergence of the Individual. New York.

Wanner, Kevin J. 2008. Snorri Sturluson and the Edda: The Conversion of Cultural Capital in Medieval Scandinavia. Toronto Old Norse-Icelandic series, 4. Toronto.

Wei, Ian P. 2012. Intellectual Culture in Medieval Paris: Theologians and the University, c. 1100-1330. Cambridge. 